\title{
Aktivitas antibakteri yogurt hasil fermentasi Lactobacillus plantarum terhadap Escherichia coli dan Staphylococcus aureus
}

\author{
Gita Nugrahani $^{1, *}$, Pratiwi Apridamayanti ${ }^{1}$, Rafika Sari ${ }^{1}$ \\ ${ }^{I}$ Program Studi Farmasi, Fakultas Kedokteran, Universitas Tanjungpura, Kalimantan Barat, Indonesia \\ *Korespondensi: gitanugrahani25@student.untan.ac.id
}

\begin{abstract}
Abstrak
Latar belakang: Yogurt merupakan produk fermentasi dari susu sapi dengan penambahan bakteri asam laktat. Bakteri asam laktat yang dapat digunakan adalah bakteri Lactobacillus plantarum. Lactobacillus plantarum diketahui memiliki senyawa antibakteri, yaitu bakteriosin, yang diharapkan dapat menambah sifat fungsional yogurt. Tujuan penelitian ini adalah untuk mengetahui karakteristik yogurt yang dihasilkan dengan starter Lactobacillus plantarum dan aktivitas antibakteri dari bakteriosin terhadap bakteri Escherichia coli dan Staphylococcus aureus. Metode: Metode yang dilakukan pada penelitian ini adalah metode difusi cakram dengan mengukur zona hambat yang dihasilkan. Hasil: Hasil dari penelitian menunjukkan karakteristik yogurt yang baik dan sesuai dengan standar SNI. Aktivitas antibakteri bakteriosin yang dihasilkan dari minuman yogurt dengan starter Lactobacillus plantarum dengan waktu inkubasi 24 jam dan 48 jam memiliki aktivitas yang lebih besar terhadap bakteri Staphylococcus aureus sebesar 11,50 mm dan 9,67 mm dibandingkan Escherichia coli yaitu sebesar 9,78 $\mathrm{mm}$ dan 8,98 mm. Kesimpulan: Yogurt hasil fermentasi Lactobacillus plantarum dengan waktu inkubasi berbeda memiliki aktivitas yang berbeda pada kedua bakteri patogen. Yogurt yang diinkubasi 24 jam dan 48 jam memiliki daya hambat yang lebih besar terhadap Staphylococcus aureus dibandingkan bakteri Escherichia coli.
\end{abstract}

Kata kunci: bakteriosin, Escherichia coli, Lactobacillus plantarum, yogurt, Staphylococcus aureus

\section{Antibacterial activity of yogurt produced through fermentation by Lactobacillus plantarum against Escherichia coli and Staphylococcus aureus}

\begin{abstract}
Background: Yogurt is a fermented product from cow's milk with the addition of lactic acid bacteria. Lactic acid bacteria that can be used are Lactobacillus plantarum. Lactobacillus plantarum is known to have antibacterial compounds, namely bacteriocin, which is expected to increase yogurt's functional properties. The purpose of this study is to determine the characteristics of yogurt produced with Lactobacillus plantarum starter and antibacterial activity produced by bacteriocin against Escherichia coli and Staphylococcus aureus. Methods: The method used in this study was the disk diffusion method by measuring the diameters of the inhibitory zones. Results: The study results showed the characteristics of good yogurt, which fulfilled SNI standards. The antibacterial activity of bacteriocin produced from yogurt using Lactobacillus plantarum starter with 24 and 48 hour incubation period against Staphylococcus aureus was higher (inhibitory zones of $11.50 \mathrm{~mm}$ and $9.77 \mathrm{~mm}$ ) than Escherichia coli (inhibitory zones of $9.78 \mathrm{~mm}$ and $8.98 \mathrm{~mm}$ ). Conclusions: Lactobacillus plantarum yogurt with different incubation periods has different activities against the two pathogenic bacteria. Yogurt incubated for 24 hours and 48 hours had a higher inhibitory capacity against Staphylococcus aureus than Escherichia coli.
\end{abstract}

Keywords: bacteriocin, Escherichia coli, Lactobacillus plantarum, yogurt, Staphylococcus aureus

\section{Pendahuluan}

Yogurt merupakan minuman fermentasi dari susu sapi dengan penambahan bakteri asam laktat sampai diperoleh keasaman, bau dan rasa yang khas. ${ }^{1}$ Yogurt mengandung probiotik yang bermanfaat untuk 
kesehatan pencernaan yang salah satunya dapat mencegah diare. Diare dapat terjadi karena infeksi dari bakteri patogen yaitu Escherichia coli dan Staphylococcus aureus. ${ }^{2}$

Pembuatan yogurt secara komersial banyak dilakukan dengan menggunakan dua jenis starter bakteri asam laktat yaitu Lactobacillus bulgaricus dan Streptococcus thermophilus. ${ }^{3}$ Yogurt probiotik dengan berbagai kultur probiotik, baik tunggal maupun campuran atau dikombinasikan dengan kultur starter yogurt konvensional telah dikembangkan. Pengembangan tersebut bertujuan dalam menghasilkan produk dengan sifat fungsional yang lebih baik. ${ }^{4}$ Starter yang dapat dikembangkan dan dimanfaatkan dalam pembuatan produk yogurt adalah Lactobacillus plantarum. Bakteri tersebut dapat digunakan sebagai starter pada proses fermentasi yang berperan dalam peningkatan produksi asam laktat. ${ }^{5}$ Lactobacillus plantarum digunakan sebagai kultur starter tunggal diketahui mampu bertahan di dalam usus dan dapat menurunkan bakteri patogen penyebab diare. ${ }^{6}$ Bakteri Lactobacillus plantarum mempunyai kemampuan menghasilkan asam dengan cepat dan lebih banyak dibandingkan dengan $L$. brevis, $L$. fermentum, dan L. Acidophilus. Selama fermentasi berlangsung jumlah sel bakteri semakin meningkat dan mampu menggeser jumlah bakteri lain selain BAL. ${ }^{7}$ Lactobacillus plantarum mampu hidup dalam kondisi asam yang rendah serta menghasilkan antimikroba bakteorisin yang mampu menekan pertumbuhan mikroba patogen. ${ }^{8}$ Bakteriosin yang berasal dari Lactobacillus plantarum yang telah teridentifikasi adalah plantaricin. ${ }^{9}$

Berdasarkan uraian tersebut diharapkan dengan penambahan kultur starter tunggal Lactobacillus plantarum pada pembuatan yogurt dapat menambah sifat fungsional yogurt dengan memanfaatkan bakteriosin yang memiliki aktivitas antibakteri terhadap bakteri patogen Escherichia coli dan Staphylococcus aureus yang dapat ditentukan dengan mengukur zona hambat yang terbentuk.

\section{Metode}

Penelitian ini dilakukan secara eksperimental melalui pengukuran aktivitas antibakteri minuman yogurt dengan starter Lactobacillus plantarum menggunakan metode difusi cakram. Pengamatan dilakukan dengan menentukan diameter zona hambat menggunakan jangka sorong. Data yang diperoleh kemudian dianalisis dengan SPSS (Statistical Program Service Solution) menggunakan uji independent sample T test.

\section{Alat dan bahan}

Alat-alat yang digunakan dalam penelitian ini adalah batang pengaduk, botol kaca $100 \mathrm{ml}$, cawan petri, filter bakteri, inkubator, jangka sorong, kawat ose, kertas cakram, dan pinset. Bahan-bahan yang digunakan akuades, larutan Mc.Farland III, glukosa, media deMan Rogosa Sharpe Agar (MRSA), media deMan Rogosa Sharpe Broth (MRSB), media Muller Hinton Agar (MHA), susu sapi, susu skim, dan yogurt komersial.

Tahapan pengujian aktivitas antibakteri dilakukan dengan metode difusi cakram. Kertas cakram dengan diameter $\pm 5 \mathrm{~mm}$ diletakkan di atas media yang telah diinokulasi dengan bakteri Escherichia coli dan Staphylococcus aureus. Diteteskan sebanyak $20 \mu \mathrm{l}$ supernatan antibakteri pada kertas cakram dan didiamkan selama 30 menit.

Selanjutnya diinkubasi pada suhu $37^{\circ} \mathrm{C}$ selama 24 jam. Zona bening yang terbentuk di sekitar kertas cakram diukur diameternya menggunakan jangka sorong. ${ }^{10}$ Supernatan antibakteri diperoleh dari yogurt yang disentrifugasi pada kecepatan 10.000 rpm selama 15 menit dan diatur suhu $4^{\circ} \mathrm{C}$. Filtrat ditambahkan $\mathrm{NaOH} 0,1 \mathrm{~N}$ untuk mencapai $\mathrm{pH}$ netral. Filtrat kemudian disaring dengan bakteri filter diameter $0,22 \mu \mathrm{m}$ untuk pensterilan sehingga diperoleh supernatan antibakteri. ${ }^{11}$

\section{Hasil}

Pengujian aktivitas antibakteri bertujuan untuk mengetahui aktivitas antibakteri bakteriosin yang dihasilkan setelah proses fermentasi menggunakan starter Lactobacillus plantarum terhadap bakteri patogen diare Escherichia coli dan Staphylococcus aureus.

Tabel 1. Aktivitas antibakteri bakteriosin Lactobacillus plantarum terhadap bakteri Staphylococcus aureus

\begin{tabular}{cccc}
\hline \multirow{2}{*}{ Replikasi } & \multicolumn{3}{c}{ Diameter zona hambat $(\mathrm{mm})$} \\
\cline { 2 - 4 } & Jam & Jam & Kontrol \\
ke-24 & 7.16 & 7.92 & 6.5 \\
& 13.48 & 10.88 & 6.75 \\
2 & 13.87 & 10.23 & 6.66 \\
3 & $11.50 \pm 3.76$ & $9.67 \pm 1.55$ & $6.63 \pm 0.12$ \\
\hline
\end{tabular}


Tabel 2. Aktivitas antibakteri bakteriosin Lactobacillus plantarum terhadap bakteri Staphylococcus aureus

\begin{tabular}{cccc}
\hline \multirow{2}{*}{ Replikasi } & \multicolumn{3}{c}{ Diameter zona hambat (mm) } \\
\cline { 2 - 4 } & Jam & Jam & Kontrol \\
ke- 24 & kesitif & posit \\
\hline 1 & 11.05 & 8.12 & 7.46 \\
2 & 9.32 & 9.29 & 7.5 \\
3 & 8.98 & 9.54 & 7.13 \\
$\mathrm{x} \pm$ SD & $9.78 \pm 1.11$ & $8.98 \pm 0.75$ & $7.36 \pm 0.20$ \\
\hline
\end{tabular}

\section{Pembahasan}

Bakteri Escherichia coli merupakan bakteri Gram negatif, sedangkan Staphylococcus aureus merupakan bakteri Gram positif. ${ }^{12,13}$ Hasil dari aktivitas antibakteri (Tabel 1 dan 2) menunjukkan adanya aktivitas antibakteri oleh bakteriosin yang diinkubasi selama 24 dan 48 jam. Hasil tersebut sesuai dengan penelitian Hasan (2018), yang menyatakan bahwa bakteriosin dihasilkan oleh bakteri Lactobacillus plantarum pada fase stasioner yaitu 18-48 jam. Pada fase stasioner terjadi keadaan seimbang antara laju pertumbuhan dengan kematian disebabkan terjadinya penipisan nutrisi sehingga bakteri asam laktat akan menghasilkan bakteriosin untuk mempertahankan diri. ${ }^{14}$

Bakteriosin yang dihasilkan pada jam ke-24 memiliki zona hambat yang lebih besar dibandingkan jam ke-48 maupun kontrol positif yaitu yogurt komersial. Perbedaan hasil tersebut karena adanya pengaruh waktu inkubasi terhadap aktivitas antibakteri yang dihasilkan oleh bakteriosin. Waktu inkubasi berhubungan dengan nutrisi media yang merupakan faktor penentu suatu bakteri dalam menghasilkan bakteriosin. Meningkatnya waktu inkubasi akan menyebabkan nutrisi pada media akan berkurang sehingga aktivitas bakteriosin cenderung menurun. ${ }^{15}$

Aktivitas bakteriosin Lactobacillus plantarum terhadap bakteri Staphylococcus aureus memiliki diameter zona hambat yang lebih besar jika dibandingkan bakteri Escherichia coli (Tabel 1 dan 2). Hal tersebut disebabkan karena bakteriosin yang dihasilkan Lactobacillus plantarum menunjukkan aktivitas antibakteri yang lebih kuat terhadap bakteri Gram positif. Sesuai dengan penelitian Prissilia ${ }^{16}$, bakteriosin yang dihasilkan Lactobacillus plantarum memiliki aktivitas antibakteri yang lebih besar pada bakteri Staphylococcus aureus sebesar 12,97 mm dan 8,863 mm terhadap Escherichia coli. ${ }^{16}$

Bakteri Gram positif memiliki reseptor spesifik yang dapat berikatan dengan bakteriosin yaitu asam lipotekoat. Bakteriosin akan menempel pada bakteri Gram positif dan membentuk kompleks dengan asam lipotekoat yang ada di dalam bakteri Gram positif sehingga terjadi ketidakstabilan pada membran. ${ }^{17}$ Ketidakstabilan membran mampu memberikan dampak pembentukan lubang atau pori pada membran sitoplasma yang mampu mengubah gradien potensial membran dan juga pelepasan molekul interseluler, serta masuknya substansi ekstraseluler. $^{18}$ Mekanisme aktivitas antibakteri bakteriosin terhadap bakteri Gram negatif yaitu dengan mengganggu lipopolisakarida serta merusak dinding sel sehingga terjadi ketidakseimbangan membran sel yang menyebabkan terbentuknya pori dan keluarnya nutrisi, ATP, serta ion. ${ }^{19}$

Zona hambat yang dihasilkan dari kontrol positif menunjukkan bahwa yogurt komersial yang berada di pasaran memiliki aktivitas antibakteri tetapi hasil zona hambatnya lebih kecil jika dibandingkan dengan bakteriosin yang dihasilkan setelah inkubasi 24 jam. Menurut standar diameter zona hambat, hasil dari zona hambat yang diperoleh dari bakteriosin terhadap bakteri Staphylococcus aureus dengan waktu inkubasi 24 jam termasuk kategori kuat sedangkan pada waktu inkubasi 48 jam termasuk kategori sedang. Hasil zona hambat terhadap Escherichia coli dengan waktu inkubasi 24 dan 48 jam termasuk kategori sedang. ${ }^{19}$

Hasil analisis dengan Uji Independent $\mathrm{T}$ test yang digunakan untuk melihat perbedaan hasil zona hambat yang terbentuk pada jam ke-24 dan jam ke-48. Hasil menunjukkan pada data zona hambat jam ke-24 dan ke-48 terhadap bakteri Escherichia coli maupun Staphylococcus aureus menunjukkan nilai signifikansi $>0.05 \%$ yaitu sebesar 0,361 dan 0,481 . Nilai signifikansi tersebut menunjukkan tidak adanya perbedaan yang bermakna pada data aktivitas antibakteri bakteriosin Lactobacillus plantarum yang diinkubasi selama 24 jam dan 48 jam.

\section{Kesimpulan}

Dari hasil yang didapat aktivitas yang dihasilkan oleh yogurt starter Lactobacillus plantarum dengan waktu inkubasi berbeda memiliki aktivitas yang berbeda pada kedua bakteri patogen. Yogurt yang diinkubasi 24 jam dan 48 jam memiliki daya hambat yang lebih besar terhadap Staphylococcus aureus dibandingkan bakteri Escherichia coli. 


\section{Daftar Pustaka}

1. Hendriani, R., Tina R., dan Sri A.G.K. Penelusuran antibakteri bakteriosin dari bakteri asam laktat dalam yoghurt asal Kabupaten Bandung Barat terhadap Staphylococcus aureus dan Escherichia coli. Bandung : Lembaga Penelitian dan Pengabdian Kepada Masyarakat Universitas Padjadjaran; 2009.

2. Siti TN, Waworuntu O, dan Porotu'o J. Pola bakteri aerob penyebab diare pada anak di Instalasi Rawat Inap Anak RSUR. W Mononginsidi Teling. Jurnal e-Biomedik. 2015;3(1):224-5.

3. Ayustaningwarno F. Teknologi pangan teori praktis dan aplikasi. Yogyakarta: Graha Ilmu; 2014.

4. Lourens-Hattingh, A. dan Viljoen, B.C. Review: Yogurt as probiotic carrier food. Int Dairy $\mathrm{J}$. 2001;11(1):1-17.

5. Reddy, G.M., Altaf, B.J. Naveena, M. Venkateshwar, E. dan Kumar, V. Amylolytic bacterial lactic acid fermentation, a review. Biotechnology Advances. 2008 Jan-Feb;26(1):22-34.

6. Arief I, Jenie BSL, Astawan M, dan Witarto AB. Efektivitas probiotik Lactobacillus plantarum 2C12 dan Lactobacillus acidophilus 2B4 sebagai pencegah diare pada tikus percobaan. Media Peternakan. 2010;1(1):137-43.

7. Afriani, Suryono, Lukman H. Karakteristik dadih susu sapi hasil fermentasi beberapa starter bakteri asam laktat yang diisolasi dari dadih asal Kabupaten Kerinci. AGRINAK. 2011:1(1):26-42.

8. Jaya F, Kusumahadi D, dan Amertaningtyas. Pembuatan minuman probi otik (yoghurt) dari proporsi susu sapi dan kedelai dengan isolat Lactobacillus casei dan Lactobacillus plantarum. Jurnal Ilmu dan Teknologi Hasil Ternak. 2011;6(1):15-7.

9. Sari R, Deslianri L, Apridamayanti P. Skrining aktivitas antibakteri bakteriosin dari minuman ce hun tiau. Pharm Sci Res. 2016;3(2):90.

10. Rizal S, Erna M, Nurainy F, dan Tambunan AR. Karakteristik probiotik minuman fermentasi laktat sari buah nanas dengan variasi jenis bakteri asam laktat. J.Kim Terapi Indonesia. 2016 ;18(1):63-71

11. Winarsi H, Septiana AT, Kartini, dan Hanifah IN. Fermentasi bakteri asam laktat meningkatkan kandungan fenolik dan serat yogurt susu kecambah kacang merah (Phaseolus vulgaris L.) minuman fungsional untuk obesitas. J.Gipas. 2019;3(1):66-7.

12. Radji, Maksum. Mikrobiologi. Jakarta: Kedokteran EGC; 2011.

13. Berg, Howard C. E. coli in motion, biological, and medical physics biomedical engineering. New York: Springer Verlag AIP Press; 2004.

14. Hasan A, dan Wikandari PR. Penentuan waktu produksi optimum bakteriosin asal Lactobacillus plantarum B1765 berdasarkan aktivitas terhadap Staphylococcus aureus. UNESA Journal of Chemistry. 2018;7(1):15-20.

15. Sifour M, Tayeb I, Haddar HO, Namous H, Aissaoi. (2012). Production and characterization of bacteriocin of Lactobacillus plantarum $\mathrm{F} 12$ with inhibitory activity against Listeria monocytogenes. 2012. TOJSAT;2(1):55-61.

16. Prissilia N. Optimasi waktu produksi bakteriosin dari Lactobacillus plantarum terhadap bakteri patogen Staphylococcus aureus dan Escherichia coli. Skripsi Sarjana Farmasi. Fakultas Farmasi, Universitas Tanjungpura Pontianak. Pontianak. 2019.

17. Nurhajati J, Atira, Aryantha INP, Kadek IDG. The curative action of Lactobacillus plantarum FNCC 226 to Saprolegnia parasitica A3 on catfish (Pangasius hypophthalmus Sauvage). IFRJ 19(4):1723-7.

18. Murray BK, et al. Biokimia Harper. Edisi 24 (Diterjemahkan oleh: Hartono A) Jakarta: EGC; 1997.

19. Greenwood, D., Slack, R., Peutherer, J. and Barer, M. Medical microbiology. China: Elsevier; 2007. 